\title{
Livelihoods, Leadership, Linkages, and Locality: The Simbo for Change Project
}

\section{Authors}

Esther Tali Suti, Simbo for Change

Lesley Hoatson, Community Development Specialist

Adimaimalaga Tafunai, Women in Business Development International

John Cox, Research Fellow, the Institute for Human Security and Social Change, La Trobe University, Bundoora, Australia

\section{Corresponding author}

John Cox, jcncox@gmail.com

49 King William St

Fitzroy

Victoria 3065

AUSTRALIA

Keywords: Community Development, Leadership, Livelihoods, South to South Cooperation, Solomon Islands

\section{Livelihoods, Leadership, Linkages, and Locality: The Simbo for Change Project}

This is the author manuscript accepted for publication and has undergone full peer review but has not been through the copyediting, typesetting, pagination and proofreading process, which may lead to differences between this version and the Version of Record. Please cite this article as doi: $10.1111 /$ apv.12260

This article is protected by copyright. All rights reserved. 


\begin{abstract}
This paper analyses the 'Simbo for Change' project in the Western Province of Solomon Islands, a collaboration between Simbo leaders and a Samoan NGO, with funding provided by the Australian aid program. We explore the role of local leadership in catalysing an island-wide community development project that has generated new livelihoods opportunities and led to greater community cohesion and more proactive governance. By mobilising around a 'collective subject' (Simbo as an island community), the project allowed existing skills and practices to be revalued and extended, particularly in relation to chiefly governance and the standing of women in the community. While mobilising the island scale was important in building social cohesion and support for livelihoods activities, this was not a parochial identity but was redefined by stronger connections to off-island markets, organic accreditation for Simbo, renewed interest from provincial and national government authorities and by the enduring trans-Pacific friendships established with the Samoan NGO and its trainers. The case study provides an example of the constructive potential of the island scale in Melanesia, whereas other recent studies of similar scale-making processes have focused on violent conflict generated by industrial scale mining.
\end{abstract}

Keywords: Community Development, Leadership, Livelihoods, South to South Cooperation, Solomon Islands

This article is protected by copyright. All rights reserved. 


\section{Livelihoods, Leadership, Linkages, and Locality: The Simbo for Change Project}

\section{Introduction}

Economic and social development is a perennial challenge in the Pacific Islands, particularly in smaller islands that do not have good connections to metropolitan centres. Isolation, distance from markets and underdeveloped transportation infrastructures have inhibited the growth of rural economies around the region. In the post-colonial Pacific, many states have struggled to maintain basic services, particularly in rural areas. Communities around the Pacific have responded with their own experiments in undertaking developmental activities in the margins of the nation state.

However, they do not always do so in their own idiom. As McKinnon et al. (2016) argue, mainstream development discourses emphasise a narrow understanding of economic development and do not value 'the rich diversity of economic practices and forms of recognition that sustain life' (McKinnon et al. 2016: 5). Mainstream development programs privilege individuals: economically as rational agents pursuing their material self-interest; or, legally, as citizens claiming their individual rights from the state. Indeed, many Melanesian women are claiming these rights for themselves, although predominantly among the urban middle class (Macintyre 2017). These individualistic configurations of development often sit uncomfortably with more collective Melanesian cultural traditions and can have the effect of devaluing local practices in relation to livelihoods and community life, even if in some cases there are also significant efforts made to integrate rights-based ideas of equality into local practices (Cox 2017).

McKinnon and her co-authors have called for more attention to be given to collective identities that embody alternative practices and that recognise the value of women's work. Drawing inspiration from Matthew Allen's recent work on how islands come to represent particular 
identities, polities and economies, particularly in cases of conflict over resource development (e.g. Allen 2016; Allen and Dinnen 2017), we examine the experience of the 'Simbo for Change' program as an example of how a collective island identity can be mobilised in support of locally-led community development and livelihoods. Allen sees the island scale as potentially 'violent or ungovernable' in relation to resistance to industrial mining projects and social and spatial inequalities, particularly among young men (Allen 2017: 81f, 87). However, Simbo for Change provides an example of the more constructive and socially cohesive potential of the island scale in Melanesia, where Simbo as an island community was mobilised as a unifying identity that aimed to address socio-spatial and gendered disadvantage through improved collective livelihoods.

This paper tracks the progression of the 'Simbo for Change' project in the Western Province of Solomon Islands, from its beginnings, its development as a project under the Pacific Leadership Program (PLP), funded by the Australian Aid program from 2012 to 2017, and through to its continuation as an ongoing local movement that is still very active now, even though external funding ceased some two years ago. We explore the role of local leadership in catalysing an island-wide community development project that has generated new livelihoods opportunities and led to greater community cohesion and more proactive governance.

The case study shows the importance of several factors; collective leadership, South to South linkages (here intra-Pacific regional networks) and mobilisation of an island identity by appealing to shared and reinvigorated social norms. We argue that Simbo for Change provides an example of Pacific-led development that has valuable lessons for community development generally, for Pacific Islanders who seek to exercise leadership for the common good and for external partners who seek to support similar movements without displacing local initiative leadership and decision-making. 
This paper draws on participatory action research undertaken during the five-year life of the project. Research methods included household surveys, interviews and participant observation, as well as subsequent reflections.

\section{The setting: Simbo in Western Solomon Islands}

Simbo is a volcanic island in Western Province of Solomon Islands. While islands are often characterised as isolated or remote (McDougall and Kere 2011: 147), Simbo has deep historical connections to the other islands around it (Dureau 2013; Gina 2003; Hviding 2014). Since the early twentieth century, these ties have been influenced by Methodist and Seventh-day Adventist mission activities, colonial rule and the formal education system, particularly boarding schools. Simbo and neighbouring Ranongga make up one constituency of the National Parliament, with the elected Member almost always coming from Ranogga, the larger of the two islands (McDougall 2016). Health and education services are national government responsibilities but are managed from Gizo, the provincial capital (Cox and Morrison 2004).

Simbo's approximately 1800 people live in four main communities around the island and speak an indigenous language, known simply as Simbo, as well as Solomon Islands Pijin. English is the language of education and often worship, and many Simbo people also speak Roviana, the language of the Methodist Mission established in the Roviana lagoon in the early Twentieth Century. The other Christian denomination on the island is the Seventh-day Adventist Church, which also came to the Western Solomons in the early 1900s. Christian missions were the initial providers of education for much of Melanesia and many Simbo people have embraced the opportunities that modern education promises and pursue professional careers in urban centres such as Gizo and Honiara, the national capital.

Like other indigenes from Solomon Islands' Western and Choiseul Provinces and Bougainville in neighbouring Papua New Guinea, Simbo people have very dark skin pigmentation relative to other Melanesians. In addition to the deep historical ties mentioned above, this distinctive 
'visibly black' (Dureau 2013) appearance contributes to a shared regional identity within (and sometimes opposed to) the nation.

Despite this long history of interconnection with other islands, the anthropologist Christine Dureau, who has conducted research on Simbo for more than 25 years, notes that Simbo people, like many other Melanesians, lament their underdevelopment and have come to see themselves as remote and disconnected from national life and prosperity (Dureau 2013: 42ff). In recent decades, Simbo has faced a range of development challenges including; a scarcity of natural resources, weak infrastructure, poor water supply and sanitation and vulnerability to natural disasters. In April 2007, an earthquake and tsunami destroyed two villages on the northern side of the island, killing ten people. Neighbouring Ranongga and Gizo islands were also badly affected by this disaster (McDougall 2016: 8).

Sources of income generation on Simbo are limited and include selling coconuts, fish and megapod eggs. Women also weave mats for sale. The nearest major market for these products is in Gizo, the capital of Western Province. Gizo is two hours travel from Simbo by outboard motor-powered canoe. High transport costs make accessing external markets and earning money difficult. As with many rural communities in the Pacific, salaried employment is minimal on Simbo but families do receive remittances from kin who have migrated (sometimes temporarily) to urban areas (cf. Wilson 2013).

Income generation in the Solomon Islands subsistence sector is based on a gendered division of labour where men do contribute to gardening and other work but women commit more of their time and have additional responsibilities (McKinnon et al. 2016; Scheyvens 2003. See also recent work by Barnett-Naghshineh 2019 and Curry, Koczberski and Inu 2019 on Papua New Guinea). As the island's main gardeners and weavers, women are the principal earners of cash income on Simbo. However, in order to sell their produce in Gizo, they are forced to spend several days at a time travelling to and from the markets there. With many women offering the same products, and the women themselves forced to buy their own food and provisions while 
away from home, cash returns for producers are often negligible. Many women are forced to 'sleep rough' at the markets, exposing them to greater risk of sexual assault, intimidation or exploitation. Many Simbo people also think that women's absences from home are a contributing factor to other social issues on the island, particularly around the proper care and protection of children and concerns about domestic violence. Simbo for Change emerged as an holistic response to these challenges, addressing both economic opportunities and questions of social cohesion.

\section{The Origins of Simbo for Change}

Simbo for Change is a locally-led community development program based on the island of Simbo that focuses on livelihoods, gender equality and family safety. Simbo for Change was initiated by Esther Tali Suti, a Simbo businesswoman based in Gizo. Esther had previously fostered savings clubs and market activities for women in Gizo, as well as managing her own business activities, including a guest house. At a personal level- and as is typical of many middle-class Melanesians (Cox 2018; Dalsgaard 2013; Gibson 2019; Rasmussen 2015)_ Esther had long nurtured a desire to contribute to the development of her home island and was looking for alternative models of doing this. However, she had not been able to find the relevant support from Solomon Islands Government agencies or their international donor partners.

In 2012, Esther's husband, Stephen Suti Agalo, was planning a business trip to Samoa, together with Anna Price, an Australian volunteer he worked with. In discussions around this visit, Anna recommended that Esther approach the Samoan NGO, Women in Business Development Inc. (WIBDI) for advice on how to approach livelihoods and other issues in Simbo. WIBDI is a Samoan business development NGO, established in 1991, that stresses 'Samoan values, tradition and culture' (WIBDI n.d.) and that has a concern for environmental sustainability (Gray et al. 2014). Moreover, WIBDI has promoted adding value to smallholder agricultural production through organic certification of villages in Samoa and other parts of the Pacific (Reinert 2017). Anna was able to source additional funding for travel that allowed Esther to 
come to Samoa. With the prior blessing of the chiefs of her tribe, Esther sought out Adimaimalaga (Adi) Tafunai, the Executive Director of WIBDI, hoping to obtain useful advice and support for developing better livelihoods opportunities for Simbo women. Esther was also looking for ways of addressing child protection through community development.

Esther and Adi found that they had much in common and became excited about the prospect of working together. Adi saw that WIBDI could provide technical support that would advance Esther's vision for Simbo but she did not have the financial means to support this. Adi had worked with the Australian Aid program before and approached the Pacific Leadership Program (PLP) for assistance. PLP saw the collaboration between Esther and WIDBI as a good opportunity to support women's leadership in rural Melanesia. PLP provided financial assistance for five years until 2017, when PLP itself closed. This funding enabled Adi Tafunai and other WIBDI program staff to travel to Solomon Islands and covered training and other expenses. While this initial support was very important as a catalyst, Simbo for Change continues as a locally-run movement now that external funding has expired.

PLP was a program founded on principles of adaptive programming where the typical donorrecipient relationships based on funding, predictable outcomes and compliance are replaced with more open-ended trust being extended to local agents so that they can use their skills, contextual knowledge and relationships more effectively (e.g. Honig and Gulrajani 2018; Hudson et al. 2018). PLP and WIBDI had previously worked together and had established a good working relationship that allowed PLP to have confidence in allowing WIBDI to take the lead in program activities, particularly in mentoring support provided to Esther (Denney and McLaren 2016: 9). PLP therefore extended a considerable degree of program autonomy to Adi and Esther in making decisions about Simbo for Change. Securing the external support from PLP gave Esther immense confidence and helped to validate her vision for the island. Esther was grateful to PLP for being prepared to listen to her perspective and for allowing the program to be guided by her local knowledge and connections. 


\section{Making viable livelihoods}

Simbo for Change has helped families to reappraise both their cash incomes and long-term food sustainability. Villagers have planted increased numbers of banana, potato and cassava as a healthy food source (rather than imported rice) and have produced excess to sell locally and in Gizo. The approach taken by WIBDI was based on utilising existing local expertise and skills and re-energising old and new livelihoods. WIBDI also focuses on households and family units as they are already established as socially viable units of production (Gray et al. 2014: 416; Coates, Hall and Skeates 2010). WIBDI also assisted in sourcing off-island markets for these goods and in adding commercial value through organic certification.

WIBDI saw that they could support Simbo communities to grow higher value crops and link growers with markets, so that women did not need to travel away from Simbo for long periods of time. They committed to walk alongside Simbo people until the quantity and quality of their produce, as well as their business acumen, were strong enough to be sustained independently of outside support. WIBDI knew that one product would be unlikely to earn everyone a large income; rather a range of high-quality products with accessible markets were needed and the steps to sustainability would take time with risks at each stage. In order to build the trust required to build an effective supply chain (Busse and Sharp 2019; Sengere, Curry and Koczberski 2018), the roll out of new products across the island had to be seen by Simbo people as fair, avoiding jealousy and the 'spoiling' of success. It was also important for the market not to be saturated and for production quality to remain high.

The program began with income-producing activities that were familiar to the women of the island, such as weaving traditional baskets and mats; screen printing Simbo designs on fabric for clothing; and trialling virgin coconut oil and coconut soap production. Esther's husband Stephen, was appointed as a part-time program manager. As an experienced apiarist and Stephen successfully trained community 'honey champions'. In three years, they increased the number of hives from 18 to 300, nearly one hive for every family on the island. The honey is 
now sold amongst Simbo people and, increasingly, on-sold to buyers in Gizo, diversifying household incomes. From January 2017 to June 2018, 1280 litres were sold for \$192,000 SBD. The cultivation of bees has also benefited fruit-bearing plants and vegetables through better pollination. In an indication of the ongoing relationships established by Simbo for Change, Stephen has recently returned to Samoa to run bee-keeping training (Samoa Observer 2018).

When new livelihoods activities faltered, Esther encouraged the community to try alternatives. For example, the coconut oil initiative did not develop as expected, so, while the initial family involved continues to make oil, community energy was redirected to other livelihoods activities such as honey production.

\footnotetext{
We started with coconut oil as it's the only product we have. It didn’t work because our electricity was too expensive, so we decided to try honey. Everyone can be involved in that and Suti knew about bees. But people were afraid of bees and they killed all of them in the first hive. But I wouldn't let the negativity stop the vision. Eventually 400 women each wanted [to produce] honey and it took four years and a lot of patience. Now most families have benefited.

Esther Suti
}

This element of experimentation encouraged community members to take responsibility for their own household livelihoods activities, rather than relying on centralised direction from the program. This in turn fostered better problem-solving and information sharing within the community. This model also resonates with many indigenous Solomon Islands subsistence horticultural practices. As Gegeo and Watson-Gegeo note, in reference to an earlier community development project in Malaita Province:

This article is protected by copyright. All rights reserved. 
The strategy of beginning one small agricultural project after another following on the initial success of the first is based on indigenous forms of agriculture, whereby diverse crops are raised together simultaneously.

Gegeo and Watson-Gegeo 2002: 388

The familiarity of these practices suggests that an important function of the project was to reframe existing livelihoods skills and work as activities now publicly recognised and revalued by the whole island community. Simbo for Change also created informal systems whereby people with particular skills were able to share them with others outside their own hosueholds and families.

\section{Simbo as an organic island}

Organic certification is one way of increasing the value of Pacific agricultural commodities in international markets (Coates, Hall and Skeates 2010: 2). The international trade in organic goods is growing quickly and can spill over into eco-tourism bringing niche travellers to sites that have only organic food (Bell 2009). In the Pacific, organic agriculture is being supported by the Secretariat of the Pacific Community through mechanisms such as the Pacific Organic and Ethical Trade Community (Organic Pasifika 2014) and through the United Nations Food and Agriculture Organisation.

WIBDI has helped to pilot accredited organic villages in Samoa (Gray et al. 2018). WIBDI identified that chemical fertilisers and insecticides had rarely been used on crops on Simbo, therefore the island could work towards organic accreditation with a view to producing higher quality produce that would receive a better financial return. WIBDI began to teach community members organic farming principles, the process of mapping gardens and looking after rubbish; pre-requisites for gaining organic accreditation. 
Simbo people didn’t first realise that being an organic island was important. Adi saw that the whole island could change. We helped people to understand that using chemicals is bad and worked to get Simbo ready for organic status, it's a pride and now other islands want this.

Esther Suti

Community members gradually articulated a long-term vision for the development of organic horticulture in Simbo. Over two years, the four villages mapped 447 gardens and cleaned the whole island in preparation for organic certification. The young men in the mapping team started to think about what they planted and became fierce advocates of organics. As an example of the mobilisation of an island scale among young men, this provides a remarkable contrast to the deployment of 'islandness' in armed conflicts over extractive resource development elsewhere in Melanesia (Allen 2017).

In July 2017, Simbo became the first island in the Solomons to be internationally accredited by the National Association for Sustainable Agriculture, Australia (NASAA), an Australian and international organic certifying agency and trade association (see also Sengere, Curry and Koczberski 2018: 233, n. 7). Simbo followed a similar certification process to Abaiang Island in Kiribati, which declared itself organic in 2013 with the support of the Pacific Organic and Ethical Trade Community (Organic Pasifika 2014).

\section{Managing Money and Saving}

Rural areas of Solomon Islands are poorly served by the banking system, which makes saving and managing money very difficult (Gegeo and Watson-Gegeo 2002: 404, n. 7). In order to create more accessible systems for managing money, Simbo for Change introduced a simple savings club program. Esther organised women into four zones, each with a savings club headed by a designated leader and another woman who would support her. Learning from other Solomon Islands groups and from WIBDI, savings clubs were formed ‘for women only', under 
the name of the island-wide women's group, the Madegugusu Women's Association, so that participants would not be overwhelmed by the enthusiasm of male members. Initially, Esther and Stephen used their own money to provide each club with a supply of flour and rice. Rather than borrowing cash as in conventional microcredit models, women were able to use the flour or rice to bake and sell their goods, repaying the cost of the flour/rice with a small amount of interest and then bank the money they made.

In early 2017, further savings club training was run with a focus on more traditional cash savings. Over 80 women attended. This in turn generated considerable curiosity from the men of Simbo and so was followed by an awareness raising for 35 men who were interested in establishing their own savings club. This model of saving provides financial intermediation service but is not a loan facility and so avoids some of the risks and adverse effects of microfinance programs elsewhere (cf. Barclay et al. 2018). These savings clubs have been successful to the point that women and men now use them to bank the returns from selling their weaving, printing, honey and garden produce. As an additional vehicle for saving, Esther negotiated with the National Provident Fund (NPF) office in Gizo for women in business groups to be able to join the NPF and save as individuals, to withdraw when they need to; and, unlike banks, they pay no monthly fees.

These initiatives have not been without tension. Some of Esther's relatives, unhappy with her level of influence within the clan, accused her of profiting from the program (an untrue claim) and set up a competing savings club run by another NGO. This club initially drew in members by promising them SBD 3000. Many participants misunderstood this as a gift, rather than a loan that had to be paid back with interest. The chiefs responded by asking the NGO not to continue its activities and church leaders have been working at reconciliation between the parties, with several women asking to be readmitted to the Madegugusu Women's Association savings clubs. 
An important feature of Simbo for Change's approach to saving has been to discuss money as an outcome of mobilising local resources in productive ways. This is a strengths-based approach (Willetts et al. 2014) that returns to the skills and resources that communities already have and revalues their own work and abilities and creates opportunities for existing expertise to be shared. In the context of Solomon Islands - where fears of aid dependency abound, often creating distrust and reinforcing political patronage networks (Cox 2009; Wood 2018) — this approach was highly strategic as it re-focused participants on their own productive capacity at the household level and without generating unrealistic expectations of windfall returns.

\section{An holistic approach to livelihoods}

Longstanding struggles with poverty and disempowerment have impacts across communities at every level. Simbo for Change did not focus on one area of intervention in isolation but addressed multiple intersecting factors that contribute to disempowerment. The timing and specific pitch of the change process was also important. While strengthening livelihoods was a major focus, as Simbo people gained confidence, they started to work on other needs. Water and sanitation, renovating the school and governance strengthening all became areas where further action was required under the program. The project tried to be as holistic and inclusive as possible, working broadly across the four tribal communities on the island and addressing cultural, livelihood, social and gender issues.

Choosing livelihoods as an early intervention point was a strategic decision in terms of gender relations. This was because Simbo women had always been capable weavers and gardeners and were respected for this expertise. These kinds of small-scale livelihoods activities were regarded as belonging largely within the field of women's work. Consequently, livelihood training did not cut across an area that men considered to be a masculine social domain. Instead, the training benefitted women and gave them more negotiating power, without explicitly disrupting the social order in a way that might generate backlash (Taylor 2008) or jealousy (Gray et al. 2014: 418). By locating the livelihoods work within existing family units, the 
project did not separate women off from men and provided a positive model of cooperative work. Men largely felt included as beneficiaries of the project, while women retained considerable control over the additional income they produced.

The broad scope of Simbo for Change frequently created a virtuous cycle where one issue fed other changes. Success in honey production increased the self-esteem (and household income) of the honey champions, while better pollination of trees improved fruit yields and food security. The community goal of every family having a hive encouraged broad engagement and ownership and averted much of the jealousy that can attend local livelihoods developments in similar contexts (Cox 2009; Foale 2001; McKinnon et al. 2016).

\section{Mobilising the island scale}

Simbo for Change has been successful at creating greater community cohesion and cooperation. For Simbo people, these changes are apparent in the visible transformation of the island environment. Simbo for Change involved an island-wide clean up, driven by hygiene concerns, the desire to make more land accessible for cultivation and by aesthetics. People cleaned their own houses, compounds and gardens and dug 100 communal and family rubbish pits. In previous decades, rubbish was simply scattered on land and in the surrounding ocean but, during the clean up, people went diving to retrieve this ocean rubbish and then dispose of it more sustainably. Communities have established daily routines of cleaning, sorting rubbish and beautifying family and tribal land. Where once tracks were over grown and scattered with waste, the bush is now clear. Esther and others point to the clearing of bush and rubbish around the island and the maintenance of pathways as reflections of a revitalised ethic of care for the island environment and a shared commitment to and pride in community life.

One of the clan chiefs described the social implications of the island clean up in the following way, emphasising collective benefits and community cohesion: 
The chiefs are thankful. We now work together with one mind. The women started to clean up and life is good from that change. We all started to work together.

Simbo for Change was not imposed by an outside agency but was initiated by a Simbo woman who worked within the informal structures of her own tribe (butubutu), the Ngarilulubi, carefully consulting with chiefs and other local leaders and then incorporating others from around the island. Although Esther was an important catalyst for change, her approach allowed others to take ownership of the program as a collective project. Because she was sensitive to local governance structures and personalities, she has been widely admired as a respectful leader. Her uncle, the chief of the largest tribe, observed these dynamics helped to build legitimacy across the island's various tribes:

She was frightened to take this leadership role but everyone respects her for coming up. We are a matrilineal culture, so the women are strong and solid. I thought my brother would be the next leader but when Esther started to come up we realised she was the one. Esther is special, she has a vision for us. How she talks, her vision, she comes down very strong. Every program she does is successful. She respects the tribe and we agree with her thoughts. Now lots of men would like to join too. Other tribes want to be part because they struggle to come up.

Esther worked at the island scale from the beginning. Because the program was seen as inclusive of the whole island's population, men and women, the chiefs encouraged everyone to be involved. This was not a matter of villagers unquestioningly following orders from their chiefs. Outsiders, following Sahlins classic (1963) typology of Pacific leadership, often misunderstand the role of chief as a kind of hereditary privilege that imbues the holder with a somewhat authoritarian disposition. This perception owes much to colonial practices of indirect 
rule, which have left an enduring legacy (McDougall 2014). However, in contemporary Solomon Islands, chiefly roles are much more fluid and the standing of an individual chief is something that must be continually worked at. Chiefly roles have changed in response to the presence or absence of the colonial and post-colonial state and have certainly been distorted by commercial interests such as logging companies (Berg 2008; McDougall 2011). At the core of the ideological role of chief (in popular Western Solomons understandings) is wise collective leadership, particularly in the resolution of local disputes, but not the pursuit of individual status and privilege (McDougall 2014: 222).

In Simbo, more traditional forms of chieftainship had been in decline for some time. In 2014, Esther had played a part in reinvigorating the role with her own tribe by supporting the investiture of her uncle, formally acknowledging him as the chief representative of the tribe. For Esther, the representative role of the chief was very important in providing a voice for herself and other women. Esther in turn was recognised as having a leadership role within her clan that allowed her to address the clan as a leader- although without the use of the title 'chief', even though there are traditions of women chiefs on Simbo (McDougall 2014: 220). The revitalisation of community life catalysed by Simbo for Change provided a new opportunity for chiefs to exercise their leadership in a publicly valued way, renewing their roles as articulators of the common good.

As mentioned earlier, Esther's leadership was regarded by some as claiming too much authority and licence. Esther was criticised for publicly raising child protection issues as others regarded this as shameful for the whole island. Esther and Stephen strongly believed that these issues could not be ignored and should be dealt with through the legal system and, in response to Facebook criticism, Stephen published child abuse reports from the Gizo police that related to Simbo. Nevertheless Esther apologised to the chiefs for raising the issue in public in ways that might be seen to diminish their authority. 
The place of women in community life has shifted through the increased social and cultural capital generated through the livelihoods activities. The voice of women has also been amplified through a renewed island-wide group: the Madegugusu Women's Association. 'Madegugusu' is Simbo for 'four places', referring to the four main villages and clans (butubutu) that constitute the island. This appeal to the island scale as an inclusive social order was effective in presenting women's empowerment as being cohesive in nature, not divisive, disorderly or confrontational.

This collective identity sits in tension with more conventional feminist ideas of women's empowerment which focus on the voice and legal rights of women as individuals (Hermkens 2013). The experience of Simbo for Change was very close to the description provided by McKinnon et al. of their Fijian and Solomon Islander research participants:

Understandings of gender equality seldom posited individual women's advancement as a central aim. Women's pursuit of an independent income was a desirable aim for gender equality that some women had put into practice. But this often ran alongside (and was in tension with) the desire for balanced and harmonious relationships with men, and greater respect and recognition of the different contributions made by women and men... (McKinnon et al. 2016: 12)

The program's success at mobilising the island's women and men through generating income (and the means to manage it through savings clubs) together with the other community benefits, has also had a positive effect on relations with the Western Provincial Government and the National Government. Politicians have been attracted by the program's achievements and see it as a model for community development elsewhere. Provincial environmental funds were given to help with waste management on Simbo and national funds were committed to a new primary school building and a vehicle. Through the project, Simbo had been reconstituted as a 
model island, firstly through the eyes of its own people and then in the gaze of provincial and national politicians and officials. With these external actors, the island scale became an example of a functioning unit of development that could be used to develop other programs elsewhere and could therefore serve as an ideological building block for the scale-making projects of the province and the national government (Allen 2017; Tsing 2005).

\section{Christianity and the Idiom of South to South Cooperation in the Pacific}

Examples of South to South cooperation are not common in the Pacific, although many Pacific Islanders do work around the region as program managers and consultants. Simbo for Change provides a case of trans-Pacific cooperation: a Samoan NGO working in Solomon Islands in partnership with local leaders (and the Australian Aid Program).

The personal friendship that developed between Esther Suti and Adi Tafunai was foundational to the success of this cooperation. For Esther, Adi was a unique role model, sharing both business and community development skills and Christian faith. Adi was an invaluable mentor to Esther as they shared a similar philosophy of leadership and development. Esther's leadership centres on Christian beliefs consistent with a century of island culture and learning. She believes God has called her and she prays for discernment to follow his plan. Her approach to development is based on mobilising what she sees as the human and natural resources that God has provided for the Simbo community. As with many other Pacific communities, Simbo people regard their island as a natural endowment that provides everything they need to sustain life (cf. Wilson 2013).

Because of the emphasis on mobilising the island's human and natural resources, even when donor money is available, Esther's focus is to ensure Simbo people do not become dependent on outsiders but use the skills and resources they have at hand. Underlying the challenge of improving the quality of living and making Simbo culture strong are core values that Esther 
frequently repeats: 'no selfishness, no hatred and no jealousy'. She works to reframe village thinking: new skills are not just about making money but provide opportunities for individuals and families to take pride in their own work and to improve the whole community's quality of life.

Christianity is the dominant religion in the Pacific and it is not uncommon for development to be couched in Christian terms (McDougall 2003; Scheyvens 2003) or for Christian churches to be seen as moderators of community standards and peace-makers in times of conflict (McDougall and Kere 2011). These Christian linkages have a deeper history to them in the Simbo case. Unbeknownst to PLP and WIBDI at the beginning of the project, Samoan Methodist missionaries first brought Christianity to Simbo in 1903. Simbo islanders think of that time as the 'first coming of the light' (Dureau 2001: 147) and so WIBDI's partnership has been called by Simbo people 'the second coming'; representing a century of trust in Samoans. Reflecting this Christian idiom, Esther regularly describes the island as being in darkness before Simbo for Change activated the population:

Simbo was a dark place, the bush was crowded in around houses, darkening surroundings and you could see no lights. Churches barely spoke with each other and villages had stopped working together.

Gray et al. (2014: 421) note the importance of organisational 'moral imperative' as a feature of successful community enterprises but do not discuss religion in this context. In the context of Simbo for Change, Christianity provided a shared language and set of public values that allowed Samoan trainers and tinoni Simbo to communicate with each other meaningfully and develop trust while imbuing everyday work, such as clearing bush tracks, with a purposeful moral significance that has built collective motivation, pride and commitment. 


\section{Conclusion}

Simbo for Change is an example of locally-led community development that began by mobilising local skills and resources, building self-reliance and then connecting the Simbo community with external trainers, resources and markets. It has several inter-related elements: bringing community together; gender awareness and empowerment; South-to-South cooperation; development of both food security and experimenting with marketable agricultural commodities (from coconut oil to honey) and then connecting in to value chains (Gizo markets and organic certification); and improved financial skills and systems for managing money. These have created a virtuous cycle that has also attracted the attention and resources of provincial and national governments.

Stories of locally-led development, such as Simbo for Change, have distinctive features that have been fundamental to their success. In this case, the individual qualities of various leaders, such as Esther and her supportive and resourceful husband Suti, were crucial to the success of the program. Strong and astute women community leaders are not unusual in Solomon Islands (McDougall 2014; Pollard and Waring 2009). Nevertheless, the inter-personal chemistry between Esther and Adi, or between Esther and her uncles, did provide a specific opportunity to drive change and manage local politics without significant resistance. This relational ecology cannot necessarily be reassembled elsewhere, although other women leaders have certainly proved adroit at mobilising their social and cultural capital to negotiate political obstacles (Spark, Cox and Corbett 2019). This caveat notwithstanding, Simbo for Change does provide some valuable lessons about the emergence of local processes of change and the place of external actors in facilitating, legitimising and resourcing these processes.

At the core of the potential lessons to be learned is the recognition that the economic and the social are interdependent. Esther and Adi would also say that the spiritual is an even more fundamental dimension of life that is overlooked in development programs. Simbo for Change did not set out to create industrial scale economic development but was focused on more 
humble and achievable livelihoods that were understood as embedded in other aspects of community life and well-being. Simbo for change appears to provide another example of the kinds of locally-led activities that McKinnon et al. (2016) describe as ‘surviving well together'.

By mobilising around what McKinnon et al. (2016: 12) refer to as a 'collective subject' (Simbo as an island community), the project allowed existing skills and practices to be revalued and extended, particularly in relation to the standing of women in the community. While mobilising the island identity was important in building cohesion and support, this was not a parochial identity but was reinforced by stronger connections to off-island markets, recognition of the organic status of Simbo, renewed interest from provincial and national government authorities and from the trans-Pacific friendships established with Adi and other Samoan trainers. In this way, Simbo for Change addressed the lack of recognition and the material inequalities that, elsewhere in Melanesia - particularly amongst communities dealing with the complex political, social and environmental consequences of industrial mining - have generated conflict articulated at the island scale (Allen 2017).

For PLP, supporting these processes was largely about allowing Adi and Esther to go about their work without imposing a set template of outcomes and without demanding that the project's outcomes should be articulated in a particular way. As Honig and Gulrajani (2016) and Hudson et al. (2018), alongside many others, argue, the structures of donor agencies struggle to accommodate the flexibility required for this kind of work to be sustained. Nevertheless, for program managers with the courage and nous to take 'Doing Development Differently' or 'Thinking and Working Politically' principles seriously, Simbo for Change provides evidence that positive results can follow from investing trust in local leadership and supporting processes of change with a ‘light touch’ by providing connections, modest resources and appropriate mentoring (Denney and McLaren 2016; Fletcher, Brimacombe and Roche 2016). 


\section{References}

Allen, M. G. (2017) Islands, extraction and violence: Mining and the politics of scale in Island Melanesia. Political Geography 57: 81-90.

Allen, M. G. and S. Dinnen (2017) Is the 'hybrid turn' a 'spatial turn'? A geographical perspective on hybridity and state-formation in the Western Pacific on scales and islands. Third World Thematics 2 (4): 500-517.

Barclay, K., N. McClean, S. Foale, R. Sulu and S. Lawless (2018) Lagoon Livelihoods: Gender and Shell Money in Langalanga, Solomon Islands. Maritime Studies 17 (2): 199-211.

Barnett-Naghshineh, O. (2019) Shame and Care: Masculinities in the Goroka Marketplace. Oceania 89 (2): 220-236.

Bell, W. (2009) Organic Agriculture and Fair Trade in Pacific Island Countries. Suva: Natural Resources Management and Environment Department, Food and Agriculture Organization of the United Nations. http://www.fao.org/3/a-ak356e.pdf Accessed 10 July 2019.

Berg, C. (2008) 'A Chief is a Chief Wherever He Goes': Land and Lines of Power in Vella Lavella, Solomon Islands. Dissertation for the degree of Dr Polit. at the University of Bergen.

Busse, M., \& Sharp, T. L. (2019). Marketplaces and Morality in Papua New Guinea: Place, Personhood and Exchange. Oceania 89(2): 126-153.

Coates, B., J. Hall, and R. Skeates. (2010) Learning from Experience: Sustainable Economic Development in the Pacific. Oxfam Discussion Paper Auckland: Oxfam New Zealand.

Cox, J. (2009) Active citizenship or passive clientelism: Accountability and development in Solomon Islands. Development in Practice 19 (8): 964-80.

Cox, J. (2017) Kindy and grassroots gender transformations in Solomon Islands, in M. Macintyre and C. Spark (eds), Transformations of Gender in Melanesia, pp. 69-94, Canberra: ANU Press.

This article is protected by copyright. All rights reserved. 
Cox, J. (2018) Fast Money Schemes: Hope and Deception in Papua New Guinea. Bloomington: Indiana University Press.

Cox, J. and J. Morrison. (2004) Solomon Islands Provincial Diagnostic Study. Report to AusAID.

https://www.academia.edu/6746443/Cox_J._and_J._Morrison._2004._Solomon_Islands_Pro vincial_Governance_Information_Paper_Accessed 10 July 2019.

Curry, G., G. Koczberski and S. M. Inu. (2019) Women's and men's work: The production and marketing of fresh food and export crops in Papua New Guinea. Oceania 89(2): 237-254.

Dalsgaard, S. (2013) The politics of remittance and the role of returning migrants: Localizing capitalism in Manus Province, Papua New Guinea. Research in Economic Anthropology, 33: 277-302.

Denney, L. and R. McLaren (2016) Thinking and Working Politically to support developmental leadership and coalitions: The Pacific Leadership Program. DLP Research Paper 40. Birmingham: Developmental Leadership Program.

Dureau, C. (2001) Recounting and remembering 'First Contact' on Simbo, in J. Mageo (ed.), Cultural Memory: Reconfiguring History and Identity in the Postcolonial Pacific, pp. 130162, Honolulu: University of Hawai'i Press.

Dureau, C. (2013) Visibly black: Phenotype and cosmopolitan aspirations in Simbo, Western Solomon Islands, in S. Trnka, C. Dureau and J. Park (eds), Senses and Citizenships: Embodying Political Life, pp. 33-54. New York and London: Routledge.

Fletcher, G., T. Brimacombe and C. Roche (2016) Power, politics and coalitions in the Pacific: Lessons from collective action on gender and power. DLP Research Paper 42. Birmingham: Developmental Leadership Program.

Foale, S. (2001) Where's our development? Land-owner expectations and environmentalist agendas in Western Solomon Islands. The Asia Pacific Journal of Anthropology 2 (2): 44-67.

Gegeo, D. and K. Watson-Gegeo. (2002) Whose knowledge?: Epistemological collisions in Solomon Islands community development. The Contemporary Pacific 14(2): 377-409. 
Gibson, L. (2019). Class, labour and consumption in urban Melanesia. In E. Hirsch and W.

Rollason (eds) The Routledge Melanesian World (pp. 164-179). London: Routledge.

Gina, L. M. (2003) Journeys in a Small Canoe: The Life and Times of a Solomon Islander. Canberra: Pandanus Press.

Gray, B., S. Duncan, J. Kirkwood and S. Walton (2014) Encouraging sustainable entrepreneurship in climate-threatened communities: a Samoan case study, Entrepreneurship \& Regional Development, 26 (5-6): 401-430.

Gray, B., J. Kirkwood, M. Etemaddar and E. Monahan (2018) Sustainable business models for community-based enterprises in Samoa and Tonga, Small Enterprise Research, 25 (2): 99-113.

Hermkens. A-K. (2013) 'Raits blong mere'? Framing human rights and gender relations in Solomon Islands. Intersections: Gender and Sexuality in Asia and the Pacific 33.

Honig, D. \& N. Gulrajani (2018) Making good on donors' desire to Do Development Differently. Third World Quarterly 39 (1): 68-84.

Hviding, E. (2014). Across the New Georgia group: A.M. Hocart's fieldwork as inter-island practice, in E. Hviding and C. Berg (eds), The Ethnographic Experiment: A.M. Hocart and W.H.R. Rivers in Island Melanesia, 1908, pp. 71-107, Oxford and New York: Berghahn Books.

Hudson, D., C. McLoughlin, H. Marquette and C. Roche. (2018) Inside the black box of political will: 10 years of findings from the Developmental Leadership Program. Developmental Leadership Program Research Paper. Birmingham: University of Birmingham.

Macintyre, M. (2017) Introduction: Flux and change in Melanesian gender relations, in M. Macintyre and C. Spark (eds), Transformations of Gender in Melanesia, pp. 1-21. Canberra: ANU Press.

McDougall, D. (2003) Fellowship and citizenship as models of national community: United Church Women's Fellowship in Ranongga, Solomon Islands. Oceania 74 (1/2): 61-80. 
McDougall, D. (2011) Church, company, committee, chief: Emergent collectivities in rural Solomon Islands, in M. Patterson and M. Macintyre (eds), Managing Modernity in the Western Pacific), pp. 121 147, St Lucia QLD: University of Queensland Press.

McDougall, D. (2014) 'Tired for nothing'? Women, chiefs, and the domestication of customary authority in Solomon Islands, in H. Choi and M. Jolly (eds), Divine Domesticities: Christian paradoxes in Asia and the Pacific, pp. 199-224, Canberra: ANU Press.

McDougall, D. (2016) Engaging with Strangers: Love and Violence in the Rural Solomon Islands. ASAO Studies in Pacific Anthropology, Vol. 6. New York and Oxford: Berghahn.

McDougall, D and J. Kere. 2011. 'Christianity, Custom and Law: Conflict and Peacemaking in the Post Conflict Solomon Islands. In M. Brigg and R. Bleiker (eds) Mediating Across Difference: Oceanic and Asian Approaches to Conflict Resolution. Honolulu: University of Hawai’i Press, 141-162.

McKinnon, K., M. Carnegie, K. Gibson and C. Rowland. (2016) Gender equality and economic empowerment in the Solomon Islands and Fiji: a place-based approach. Gender, Place and Culture 23(10): 1376-1391.

Organic Pasifika (2014) 'The Community of Abaiang rallies around organic island declaration'. 22 Oct 2014. https://lrd.spc.int/about-organic-pasifika/pacific-organic/-thecommunity-of-abaiang-rallies-around-organic-island-declaration Accessed 8 Dec 2018.

Pollard, A. and M. Waring (eds) (2009) Being the first: Storis blong oloketa mere lo Solomon Aelan, Honiara and Auckland: RAMSI and Pacific Media Centre.

Rasmussen, A. (2015). In the Absence of the Gift: New Forms of Value and Personhood in a Papua New Guinea Community. London: Berghahn.

Reinert. M. (2017) 'Pacific: Organic on the Horizon'. 20 Mar 2017. http://spore.cta.int/en/trade/organic-on-the-horizon.html Accessed 8 Dec 2018

Samoa Observer (2018) Savai'i holds key to organic honey industry. 11 Nov 2018. https://www.samoaobserver.ws/category/samoa/12349 Accessed 15 July 2019 
Scheyvens, R. (2003) Church women's groups and the empowerment of women in Solomon Islands. Oceania 74 (1/2): 24-43.

Sengere, R., G. Curry and G. Koczberski (2018) Forging alliances: Coffee grower and chain leader partnerships to improve productivity and coffee quality in Papua New Guinea. Asia Pacific Viewpoint 60 (2): 220-235.

Spark, C., J. Cox and J. Corbett. (2019) Gender, political representation and symbolic capital: How some women politicians succeed. Third World Quarterly 40 (7): 1227-1245.

Tsing, A. 2005. Friction: An Ethnography of Global Connection. Princeton NJ: Princeton University Press.

Wilson, K. (2013) Wan laki aelan? Diverse development strategies on Aniwa, Vanuatu. Asia Pacific Viewpoint 54 (2): 246-263.

Willetts, J., S. Asker, N. Carrard and K. Winterford (2014) The practice of a strengths-based approach to community development in Solomon Islands. Development Studies Research 1 (1): 354-367.

Women in Business Development Incorporated (WIBDI). No date. https://www.womeninbusiness.ws/ accessed 8 Dec 2018.

Wood, T. (2018). The clientelism trap in Solomon Islands and Papua New Guinea, and its impact on aid policy. Asia \& the Pacific Policy Studies 5(3): 481-494.

This article is protected by copyright. All rights reserved. 


\section{Livelihoods, Leadership, Linkages, and Locality: The Simbo for Change Project}

\section{Authors}

Esther Tali Suti, Simbo for Change

Lesley Hoatson, Community Development Specialist

Adimaimalaga Tafunai, Women in Business Development International

John Cox, Research Fellow, the Institute for Human Security and Social Change, La Trobe University, Bundoora, Australia

\section{Corresponding author}

John Cox, jcncox@gmail.com

49 King William St

Fitzroy

Victoria 3065

AUSTRALIA

Keywords: Community Development, Leadership, Livelihoods, South to South Cooperation, Solomon Islands 


\section{University Library}

\section{- M M N E R VA A gateway to Melbourne's research publications}

Minerva Access is the Institutional Repository of The University of Melbourne

Author/s:

Suti, E;Hoatson, L;Tafunai, A;Cox, J

Title:

Livelihoods, leadership, linkages and locality: The Simbo for Change project

Date:

2020-02-05

Citation:

Suti, E., Hoatson, L., Tafunai, A. \& Cox, J. (2020). Livelihoods, leadership, linkages and locality: The Simbo for Change project. ASIA PACIFIC VIEWPOINT, 62 (1), pp.15-26. https:// doi.org/10.1111/apv.12260.

Persistent Link:

http://hdl.handle.net/11343/276838 